\title{
A concise review of hepatitis $C$ in heart and lung transplantation
}

\author{
Edward Kim MD CCFP ${ }^{*}$, Hin Hin Ko MD FRCPC ${ }^{2 *}$, Eric M Yoshida MD MHSc FRCPC $2,3,4$
}

\begin{abstract}
E Kim, HH Ko, EM Yoshida. A concise review of hepatitis C in heart and lung transplantation. Can J Gastroenterol $2011 ; 25(8): 445-448$.

Hepatitis $\mathrm{C}(\mathrm{HCV})$ infection is prevalent in recipients of, and candidates for, solid organ transplants. The outcomes of HCV infection in cardiac and lung transplant recipients have yet to be clearly established, and future prospective studies are needed. In the absence of safe and effective antiviral treatment for $\mathrm{HCV}$ infection in heart and lung transplant recipients, the management of these patients remains a challenge and must be considered on an individual basis. Interferon therapy for HCV before transplantation appears to improve outcomes; however, post-transplant interferon therapy in the cardiac and pulmonary transplant setting may be associated with an increased risk of graft rejection. Given the paucity of information regarding HCV treatment in these transplant recipients, and with appropriate concerns that graft loss from rejection may not be amenable to a second transplant (given the scarcity of suitable cadaveric organs), multicentre, randomized controlled trials are needed to determine the optimal approach for treatment of $\mathrm{HCV}$ infection in this population.
\end{abstract}

\section{Une revue concise de l'hépatite $\mathrm{C}$ en cas de greffe cœur-poumons}

L'infection par l'hépatite C (VHC) est prévalente chez les greffés d'organes solides et les candidats à de telles greffes. Les issues de l'infection par le VHC chez les greffés cœur-poumons ne sont pas clairement établies, et des études prospectives s'imposent sur le sujet. En l'absence d'antivirothérapie sécuritaire et efficace chez les greffés cœur-poumons, la prise en charge demeure difficile et doit être évaluée sur une base individuelle. La thérapie à l'interféron contre le VHC avant la greffe semble améliorer les issues, mais si elle est utilisée après une greffe cœur-poumons, elle peut s'associer à une augmentation du risque de rejet de la greffe. Étant donné le peu d'information au sujet du traitement du VHC chez les greffés et puisqu'il se peut que la perte de la greffe attribuable à un rejet ne puisse pas être suivie d'une deuxième greffe (en raison du peu d'organes cadavériques appropriés), des études aléatoires et contrôlées multicentriques s'imposent afin de déterminer la démarche optimale pour traiter l'infection par le VHC au sein de cette population.

Key Words: Heart; Hepatitis C; Interferon; Lung; Rejection; Transplant; Treatment

W eart and lung transplantation are significant life-saving interLentions that can lead to improved quality of life for patients with refractory cardiac and respiratory failure. Success with transplantation requires ongoing immunosuppression to prevent immune graft rejection. Unfortunately, persistent viral infections in donors may be transmitted to recipients in the process of organ transplantation. With the severe shortage of available organs and significant wait-list mortality, the use of organs from donors with hepatitis $\mathrm{C}$ virus (HCV) infection has been considered. Given this donor shortage, which has resulted in a tragic disparity between those in need of cardiac and/or pulmonary transplant and its availability, an understanding of the outcome and management of HCV infection in this population is essential. We review the data regarding outcomes of patients with pre-existing chronic HCV infection undergoing cardiac transplantation, and the impact of de novo HCV infection following transplantation. Furthermore, a therapeutic approach to this group of patients is also discussed.

\section{PRE-EXISTING HCV INFECTION IN CARDIAC TRANSPLANTATION}

There are limited studies addressing the outcome of pre-existing HCV infection in heart transplant (HT) recipients. Despite the reluctance of many centres to perform $\mathrm{HT}$ in $\mathrm{HCV}$-positive $\left(\mathrm{HCV}^{+}\right)$patients, pre-existing HCV infection has not been clearly shown to increase all-cause mortality among HT recipients. A retrospective study with $96 \mathrm{HCV}^{+} \mathrm{HT}$ recipients (1) reported no difference in mortality rates, but an increased incidence of liver-related deaths when compared with uninfected patients. A more recent study followed 11 patients with pre-existing chronic HCV for a mean of 32 months (2), and evaluated liver function laboratory parameters, pre- and postsurgical hepatobiliary ultrasounds and mortality. No abnormalities in the liver parenchyma were observed on the ultrasound examinations performed before or after heart transplantation. There were three deaths (27\%), none of which were related to HCV infection. No morphological or laboratory abnormalities were observed to suggest reactivation of the infection during the follow-up period. However, a six-year follow-up evaluation of $36 \mathrm{HCV}^{+} \mathrm{HT}$ recipients (3) reported that 21 patients (58\%) developed 'chronic liver disease', defined as liver enzyme levels greater than 1.5 times the upper limit of normal, with clinically relevant cirrhosis in $28 \%$. Three of these six cirrhotic patients, all with de novo $\mathrm{HCV}$ infection, died of end-stage liver disease at a mean of six years after heart transplantation. A recent study assessed the clinical outcomes of $224 \mathrm{HCV}$-seropositive HT recipients (4), and found reduced survival rates compared with their HCV-negative counterparts. However, the adjusted RR of recipient HCV-seropositive versus HCVseronegative status did not reach statistical significance after adjusting for other donor and recipient factors. There was also no statistically significant difference in acute rejection episodes in the first year after transplantation between the two groups.

\footnotetext{
*Co-primary authors. ${ }^{1}$ Gastroenterology Fellowship Program; ${ }^{2}$ Division of Gastroenterology; ${ }^{3}$ BC Hepatitis Program; ${ }^{4}$ BC Transplant Society,

University of British Columbia, Vancouver, British Columbia

Correspondence: Dr Eric M Yoshida, Division of Gastroenterology, Gordon and Leslie Diamond Health Care Centre, 5153-2775 Laurel Street,

Vancouver, British Columbia V5Z 1M9. Telephone 604-875-5039, fax 604-875-5447, e-mail eric.yoshida@vch.ca

Received for publication October 25, 2010. Accepted January 28, 2011
} 


\section{DE NOVO HCV INFECTION AFTER CARDIAC TRANSPLANTATION}

Transplantation of HCV antibody-positive donor organs into uninfected recipients almost uniformly results in chronic HCV infection in the immunocompromised host, with reported transmission rates ranging from $7 \%$ to $82 \%(5-7)$. However, most of these studies were limited by the lack of serum HCV RNA testing in the cadaveric donors at the time of organ procurement. Reportedly, almost one-third of HT recipients with HCV infection have an undetectable level of anti-HCV antibiodies as a consequence of their immunocompromised state $(5,6,8,9)$. Furthermore, Lunel et al (10) showed that patients with de novo HCV infection following cardiac transplantation have a significant delay between elevation of aminotransferase levels or HCV RNA detection and anti-HCV detection. In addition to the substantial risk of HCV transmission to the transplant recipient, high rates of subsequent liver enzyme abnormalities have been reported (6). Many patients who acquired $\mathrm{HCV}$ in the peri- or post-transplant period developed chronic hepatitis, with more severe liver disease found in those coinfected with hepatitis B virus (HBV) and HCV $(3,11)$.

Marelli et al (7) reported HCV transmission in only $25 \%$ of HT recipients under similar circumstances. In contrast, a prospective study by Ong et al (5), found that 23 of 28 recipients (82\%) of donor $\mathrm{HCV}^{+}$ hearts became HCV RNA positive. Seven of these patients (30\%) developed HCV-related liver disease, four progressing to severe cholestatic hepatitis. Risk factors for severe hepatitis included the use of mycophenolate mofetil and high HCV viral load. However, overall survival was similar to that seen in a matched control HCV-negative donor population, without significant short-term differences in the rate of fibrosis progression when compared with immunocompetent patients with HCV infection. Several small studies also found that de novo HCV infection did not appear to reduce both short-term and intermediateterm survival after cardiac transplantation $(5,10)$ (Table 1).

However, development of acute cholestatic hepatitis and mycophenolate use have been independently associated with increased mortality in patients with de novo HCV infection $(5,12)$. In addition, mortality among 34 recipients of $\mathrm{HCV}^{+}$donor hearts was 2.8-fold (95\% CI 1.3 to 5.9) greater than controls at the Cleveland Clinic (USA) (13). More recently, a multicentre cohort study was performed to assess all-cause mortality in 261 patients who received an $\mathrm{HCV}^{+}$ donor heart (14). Mortality was higher among recipients of $\mathrm{HCV}^{+}$ donor hearts at one, five and 10 years, who were more likely to die of liver disease and coronary vasculopathy, independent of recipient HCV status or age.

\section{TREATMENT OF HCV IN A CARDIAC TRANSPLANT POPULATION}

In 1998, Fagiuoli et al (15) reported treatment of three HT recipients with chronic HCV infection with interferon (IFN) (5 million units of IFN-alpha three times per week) without development of acute cellular rejection during therapy. A few years later, the same investigators treated five HT recipients with chronic HCV and one with combined HBV/HCV chronic infection (16). The mean ( \pm SD) follow-up after HT was $8.5 \pm 3$ years, and the patients received natural leukocyte IFN (IFN-alpha-N3) at a dose of 6 million units intramuscularly three times per week for 12 months. Follow-up continued for at least 12 months after treatment. All patients completed the treatment with no major side effects. The patient with combined HBV/HCV infection showed complete biochemical and virological responses (ie, the HBV DNA and HCV RNA were negative at the third month). Sustained response was achieved over a 12 -month follow-up. Of the four HT recipients with chronic HCV infection, three (75\%) exhibited sustained biochemical responses after a 12-month follow-up period. In addition, HCV RNA was negative in three patients by the third month of treatment; however, virological response was not sustained at the end of IFN treatment and during follow-up. A recent case report (17) documented a fatality after IFN/ribavirin treatment for chronic HCV in a 50-year-old orthoptic HT recipient transplanted for ischemic cardiomyopathy. Elevated liver enzyme levels one year after heart transplantation (alanine aminotransferase $246 \mathrm{U} / \mathrm{L}$; aspartate aminotransferase $123 \mathrm{U} / \mathrm{L}$ ) were attributed to pre-existing HCV infection in the setting of immunosuppression. Liver biopsy revealed chronic hepatitis with moderate fibrosis and mild activity. HCV was treated with pegylated IFN-2b and ribavirin for six months, with liver enzyme results gradually returning to the normal range. At that time, ribavirin was discontinued while pegylated IFN was continued. The patient ultimately presented with severe heart failure and succumbed to arrhythmia refractory to medical treatment. At autopsy, the patient was found to have patent coronary arteries, diffuse severe fatty degeneration of heart myocytes, and no evidence of cellular or humoral rejection, which was believed to be confirmatory of cardiotoxicity from pegylated IFN alpha-2b.

Aside from antiviral therapy, other agents, such as ursodeoxycholic acid (ursodiol), have also been evaluated for treatment of chronic viral hepatitis in the HT population. Several studies, including a metaanalysis (18), have reported the beneficial effect of ursodiol on liver biochemistry in patients with chronic hepatitis. In 2003, however, a double-blind randomized controlled trial by Cadranel et al (19) concluded that a one-year course of ursodiol did not have any effect on liver biochemistry or histology in HT patients with chronic HCV.

In summary, although two small pilot studies demonstrated that IFN monotherapy might be effective and well-tolerated in the treatment of HCV in HT recipients, further studies are still needed to assess the efficacy of IFN-based antiviral therapy in this population. As in renal allograft recipients, IFN-based antiviral therapy may place HT recipients at a higher risk of graft rejection allograft failure from cardiotoxicity. The adverse effect profile of the combination of IFN and ribavirin can also affect the tolerability of these medications. Given these limitations, development of more effective treatments with improved side effect profiles is needed.

\section{HCV IN LUNG TRANSPLANT RECIPIENTS}

There are limited data regarding outcomes after lung transplantation in recipients with pre-existing or de novo HCV infection. In 1998, Cotler et al (20) surveyed all United Network of Organ Sharingapproved lung transplant centres in the United States to evaluate practices regarding $\mathrm{HCV}$-infected donors, recipients and to gather preliminary data on the outcomes of lung transplant recipients with HCV. This survey study revealed that all programs screened potential organ donors and lung transplant candidates for HCV using antibody testing. When it came to policies regarding transplantation of HCVinfected candidates, they determined that 33 of 46 (72\%) programs considered HCV-infected candidates for transplantation, while 26 of 47 (55\%) accepted lung allografts from seropositive donors. In addition, eight of 48 (17\%) had transplanted lung allografts from seropositive donors into uninfected recipients. However, the survey indicated that post-transplant monitoring of patients with HCV varied significantly. Biochemical evidence of hepatitis was noted following transplantation in six of $14 \mathrm{HCV}$ donor-positive/recipient-negative cases; however, no verifiable HCV-related deaths were reported in lung transplant recipients in any of these cases. The progression of liver injury in patients with HCV following lung transplantation could not be evaluated due to incomplete histological data. The authors concluded that more studies were needed to evaluate outcomes of HCV. infected lung transplant recipients. However, in 2001, Carreno et al (21) presented a small case series of three patients who acquired HCV after lung transplantation. All three patients developed elevated liver enzyme levels post-lung transplantation, which ultimately led to the diagnosis of HCV. Each of these patients had high viral loads and were infected with genotype $1 \mathrm{~b}$. All died within one year of transplant; two died of hepatic failure despite treatment and one died from hemoptysis due to fungal infection. The authors concluded that in lung transplant recipients, post-transplant HCV infection portended a poor prognosis. 
TABLE 1

Summary of pre-existing and de novo hepatitis C virus (HCV) infection in patients undergoing heart transplantation

\begin{tabular}{|c|c|c|c|c|c|}
\hline $\begin{array}{l}\text { Author } \\
\text { (reference), year }\end{array}$ & $\begin{array}{l}\text { Study type, } \\
\text { patients, } \mathrm{n}\end{array}$ & HCV infection & $\begin{array}{l}\text { Follow-up } \\
\text { period }\end{array}$ & Survival & Comments \\
\hline Lake et al (1), 1997 & Retrospective, 96 & $\begin{array}{l}33 \text { pre-existing, } 27 \\
\text { de-novo, } 36 \text { unknown }\end{array}$ & 4 years & No mortality difference & Increased liver-related deaths in $\mathrm{HCV}^{+}$patients \\
\hline Ong et al (5), 1999 & Retrospective, 28 & De novo & 28 months & No mortality difference & $\begin{array}{l}\text { Acute cholestatic hepatitis, mycophenolate } \\
\text { mofetil use associated with decreased survival }\end{array}$ \\
\hline Lunel et al (10), 2000 & Retrospective, 49 & De novo & 5 years & No mortality difference & $\begin{array}{l}\text { Liver histology did not progress rapidly in } \mathrm{HCV}^{+} \\
\text {patients }\end{array}$ \\
\hline $\begin{array}{l}\text { Fagiuoli et al (3), } \\
2001\end{array}$ & Retrospective, 36 & $\begin{array}{l}8 \text { pre-exisiting, } \\
18 \text { de-novo, } 10 \text { unknown }\end{array}$ & 6 years & Not evaluated & $\begin{array}{l}21 \text { patients (58\%) developed 'chronic liver } \\
\text { disease', } 6 \text { with cirrhosis. Three of } 6 \text { cirrhotic } \\
\text { patients (de novo } \mathrm{HCV}^{+} \text {) died of end-stage } \\
\text { liver disease a mean } 6 \text { years after transplant }\end{array}$ \\
\hline Haji et al (13), 2004 & Retrospective, 34 & De novo & 4 years & Increased mortality & $\begin{array}{l}\text { Mortality was } 2.8 \text { fold greater in } \mathrm{HCV}^{+} \text {patients } \\
\text { over controls, increased risk of advanced } \\
\text { vasculopathy }\end{array}$ \\
\hline $\begin{array}{l}\text { Gasink et al (14), } \\
2006\end{array}$ & $\begin{array}{l}\text { Multicentre cohort } \\
\text { study }\end{array}$ & De-novo & 10 years & Increased mortality & $\begin{array}{l}\text { Mortality higher among recipients of } \mathrm{HCV}^{+} \text {donor } \\
\text { hearts at } 1,5 \text { and } 10 \text { years; more likely to die } \\
\text { of liver disease and coronary vasculopathy, } \\
\text { independent of recipient } \mathrm{HCV} \text { status or age }\end{array}$ \\
\hline Cano et al (2), 2007 & Retrospective, 11 & Pre-existing & 32 months & Not evaluated & $\begin{array}{l}\text { No abnormalities were observed on liver } \\
\text { ultrasounds performed serially after } \\
\text { transplantation. Three deaths ( } 27 \%) \text {, } \\
\text { unrelated to HCV. No morphological or } \\
\text { laboratory abnormalities were observed to } \\
\text { suggest reactivation of HCV during follow-up }\end{array}$ \\
\hline Fong et al (4), 2009 & Retrospective, 224 & Pre-existing & 5 years & Increased mortality & $\begin{array}{l}\text { Adjusted } \mathrm{RR} \text { of recipient } \mathrm{HCV}^{+} \text {versus } \mathrm{HCV}^{-} \\
\text {status not statistically significant after } \\
\text { adjusting for other donor and recipient factors. } \\
\text { Increased incidence of liver-related deaths. } \\
\text { No difference in acute rejection episodes in } \\
\text { the first year }\end{array}$ \\
\hline
\end{tabular}

$\mathrm{HCV}^{-} \mathrm{HCV}$ negative; $\mathrm{HCV}^{+} \mathrm{HCV}$ positive

Conversely, a small retrospective cohort study by Sahi et al (22) did not find any significant difference in patient or graft survival between $\mathrm{HCV}^{+}$lung transplant recipients and $\mathrm{HCV}$-negative recipients. Six patients were identified to be $\mathrm{HCV}^{+}$before lung transplantation. Marked increase in HCV RNA levels were found post-transplant, but without concomitant increases in transaminase levels. No significant increase in acute rejection was found in the first year posttransplant in $\mathrm{HCV}^{+}$lung transplant recipients. This study, although limited by its small cohort size, short duration of follow-up and its retrospective nature, did not find that short-term outcomes after lung transplant were different for patients with chronic HCV compared with those who were HCV negative. The authors suggested that patients should not be denied transplantation candidacy solely based on their HCV status; instead, the decision to transplant should be based on liver function parameters and the severity of liver pathology.

In 2007, Doucette et al (23) described the outcomes of HCV treatment in five lung transplant candidates, modelled on the suggested approach to $\mathrm{HCV}$-infected renal transplant candidates. Patients were identified after referral for lung transplant assessment who were HCV antibody and HCV RNA positive, and otherwise acceptable transplant candidates. These patients were determined to be candidates for HCV therapy based on 'published guidelines'. Five patients were treated with standard HCV therapy at time of presentation: ribavirin plus either IFN-alpha $2 b$ or pegylated IFN alpha-2b for 24 (genotype 3 ) or 48 weeks (genotype 1 ) . During treatment, all patients experienced the anticipated adverse effects of IFN and ribavirin (eg, flu-like symptoms, anemia and mild leukopenia). One patient discontinued treatment due to anxiety, which the authors believed was IFN related. Three patients exhibited sustained virological response, and one patient underwent uncomplicated lung transplant with immunosuppression using cyclosporine, mycophenolate mofetil and prednisone. At nine months, post-transplant rejection was clinically diagnosed after an upper respiratory tract infection and the patient was treated with methylprednisolone. At 21 months post-transplant, she continued to exhibit excellent lung function with a forced expiratory volume in $1 \mathrm{~s}$ $\left(\mathrm{FEV}_{1}\right)$ of $2.01 \mathrm{~L}$ (69\% predicted); her HCV-RNA remains negative with normal liver enzyme levels and liver function. Another patient experienced an end-of-treatment response (HCV-RNA negative), but relapsed with a positive HCV RNA six months after completing therapy. Liver biopsy showed only moderate disease, and he subsequently underwent lung transplant. He experienced two episodes of rejection, one responding to methylprednisolone, and one requiring thymoglobulin. Liver enzyme levels remained normal, and his $\mathrm{FEV}_{1}$ was $2.2 \mathrm{~L}$ (62\% predicted) seven months post-transplant. The fifth patient completed 48 weeks of therapy for genotype $1 \mathrm{HCV}$ infection and, despite a negative HCV-RNA at week 12, her end-of-treatment HCV-RNA was positive. Liver biopsy showed only mild disease; this patient was awaiting transplant (23). Although it has been suggested that lung transplant candidates would be poor candidates for $\mathrm{HCV}$ treatment because most hepatologists in the nontransplant setting would be very reluctant to offer treatment to patients with end-stage lung disease, this small study suggested that this population could be treated for HCV safely and effectively. The authors concluded that it may be inappropriate to exclude otherwise acceptable lung transplant candidates on the basis of HCV infection as recommended by the 2006 international guidelines for the selection of lung transplant candidates (24).

Currently, robust clinical studies regarding the outcomes of chronic HCV infection, and the safety and efficacy of IFN-based HCV therapy in lung transplant recipients have not been reported and additional definitive studies are required. The potential adverse effects of antiviral therapy and the risk of graft rejection would have to be carefully considered and might outweigh the benefit of antiviral therapy for $\mathrm{HCV}$ in this population. 


\section{SUMMARY}

Hepatitis $\mathrm{C}$ infection is prevalent in recipients of, and candidates for, solid organ transplants. The outcomes of HCV in recipients of cardiac and lung transplants have yet to be clearly established, and future prospective studies are needed. In the absence of safe and effective antiviral treatment for HCV infection in HT and lung transplant recipients, the management of these patients remains a challenge and must be considered on an individual basis. There is limited published experience with IFN therapy for HCV before cardiac transplantation, which may be limited by the concerns regarding safety and tolerability of IFN and ribavirin in this population. Furthermore, post-transplant IFN therapy in the cardiac and pulmonary transplant setting may be associated with an increased risk of graft rejection. Given the paucity of information on HCV treatment in these transplant recipients, and with appropriate concerns that graft loss from rejection may not be amenable to a second transplant (given the scarcity of suitable cadaveric organs), multicentre, randomized controlled trials are needed to determine the optimal approach for treatment of $\mathrm{HCV}$ infection in this population.

\section{REFERENCES}

1. Lake KD, Smith CI, Milfred-La Forest SK, Pritzker MR, Emery RW. Outcomes of hepatitis $\mathrm{C}$ positive $\left(\mathrm{HCV}^{+}\right)$heart transplant recipients. Transplant Proc 1997;29:581-2.

2. Cano O, Almenar L, Martinez-Dolz L, et al. Course of patients with chronic hepatitis $\mathrm{C}$ virus infection undergoing heart transplantation. Transplant Proc 2007;39:2353-4.

3. Fagiuoli S, Minniti F, Pevere S, et al. HBV and HCV infections in heart transplant recipients. J Heart Lung Transplant 2001;20:718-24.

4. Fong TL, Hou L, Hutchinson IV, Cicciarelli JC, Cho YW. Impact of hepatitis $\mathrm{C}$ infection on outcomes after heart transplantation. Transplantation 2009;88:1137-41.

5. Ong JP, Barnes DS, Younossi ZM, et al. Outcome of de novo hepatitis $\mathrm{C}$ virus infection in heart transplant recipients. Hepatology 1999;30:1293-8.

6. Pfau PR, Rho R, DeNofrio D, et al. Hepatitis C transmission and infection by orthotopic heart transplantation. J Heart Lung Transplant 2000;19:350-4.

7. Marelli D, Bresson J, Laks H, et al. Hepatitis C-positive donors in heart transplantation. Am J Transplant 2002;2:443-7.

8. Pereira BJ, Milford EL, Kirkman RL, Levey AS. Transmission of hepatitis C virus by organ transplantation. N Engl J Med 1991;325:454-60.

9. Zein NN, McGreger CG, Wendt NK, et al. Prevalence and outcome of hepatitis $\mathrm{C}$ infection among heart transplant recipients. J Heart Lung Transplant 1995;14:865-9.

10. Lunel F, Cadranel JF, Rosenheim M, et al. Hepatitis virus infections in heart transplant recipients: Epidemiology, natural history, characteristics, and impact on survival. Gastroenterology 2000;119:1064-74.

11. Pereira BJ, Milford EL, Kirkman RL, et al. Prevalence of hepatitis C virus RNA in organ donors positive for hepatitis $\mathrm{C}$ antibody and in the recipients of their organs. N Engl J Med 1992;327:910-5.

12. Izquierdo MT, Almenar L, Zorio E, Martinez-Dolz L. [Viral hepatitis C-related fibrosing cholestatic hepatitis after cardiac transplantation.] Med Clin (Barc) 2007;129:117-8.

13. Haji SA, Starling RC, Avery RK, et al. Donor hepatitis C seropositivity is an independent risk factor for the development of

accelerated coronary vasculopathy and predicts outcome after cardiac transplantation. J Heart Lung Transplant 2004;23:277-83.

14. Gasink LB, Blumberg EA, Localio AR, Desai SS, Israni AK, Lautenbach E. Hepatitis $C$ virus seropositivity in organ donors and survival in heart transplant recipients. JAMA 2006;296:1843-50.

15. Fagiuoli S, Cooper DK, Zuhdi N. Hepatitis C status of heart transplant recipients. Clin Transplant 1998;12:5-10.

16. Fagiuoli S, Pevere S, Minniti F, et al. Natural leukocyte interferon alfa for the treatment of chronic viral hepatitis in heart transplant recipients. Transplantation 2003;75:982-6.

17. Wang BY, Chang HH, Chen IM, Shih CC, Yang AH. Peginterferon alpha-2b and acute allograft failure in a heart transplant recipient. Ann Thorac Surg 2010;89:1645-7.

18. Simko V, Michael S, Prego V. Ursodeoxycholic therapy in chronic liver disease: A meta-analysis in primary biliary cirrhosis and in chronic hepatitis. Am J Gastroenterol 1994;89:392-8.

19. Cadranel JF, Di Martino V, Dorent R, et al. Effects of ursodeoxycholic acid (ursodiol) treatment on chronic viral hepatitis in heart transplant patients: Results of a prospective, double-blind, placebo-randomized study. Transplantation 2003;75:977-82.

20. Cotler SJ, Jensen DM, Kesten S. Hepatitis $C$ virus infection and lung transplantation: A survey of practices. J Heart Lung Transplant 1999;18:456-9.

21. Carreno MC, Piedad UG, Maite L, et al. Hepatitis C virus infection after lung transplantation: Dim prognosis. J Heart Lung Transplant 2001;20:224.

22. Sahi H, Zein NN, Mehta AC, Blazey HC, Meyer KH, Budev M. Outcomes after lung transplantation in patients with chronic hepatitis C virus infection. J Heart Lung Transplant 2007;26:466-71.

23. Doucette KE, Weinkauf J, Sumner S, Ens K, Lien D. Treatment of hepatitis $\mathrm{C}$ in potential lung transplant candidates. Transplantation 2007;83:1652-5.

24. Orens JB, Estenne M, Arcasoy S, et al. International guidelines for the selection of lung transplant candidates: 2006 update - a consensus report from the Pulmonary Scientific Council of the International Society for Heart and Lung Transplantation. J Heart Lung Transplant 2006;25:745-55. 


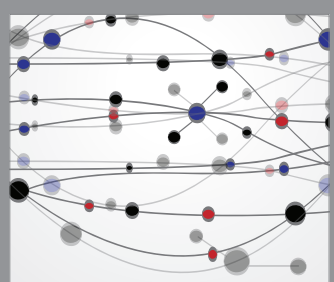

The Scientific World Journal
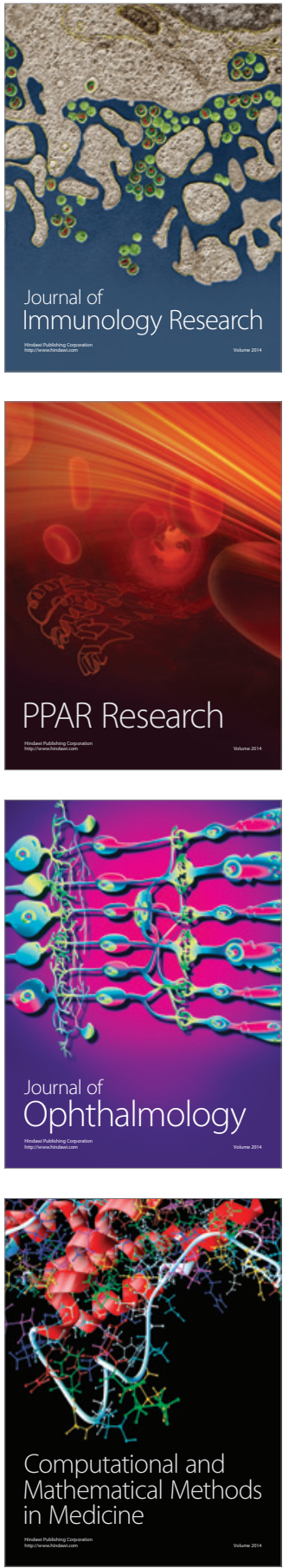

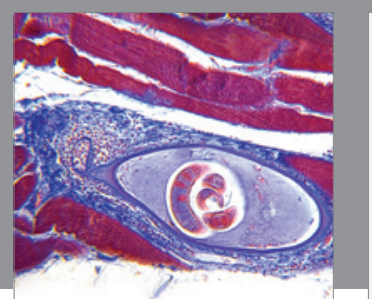

Gastroenterology Research and Practice

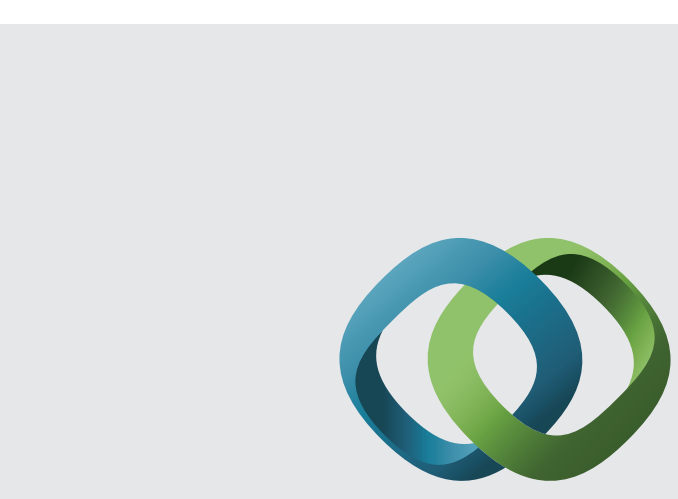

\section{Hindawi}

Submit your manuscripts at

http://www.hindawi.com
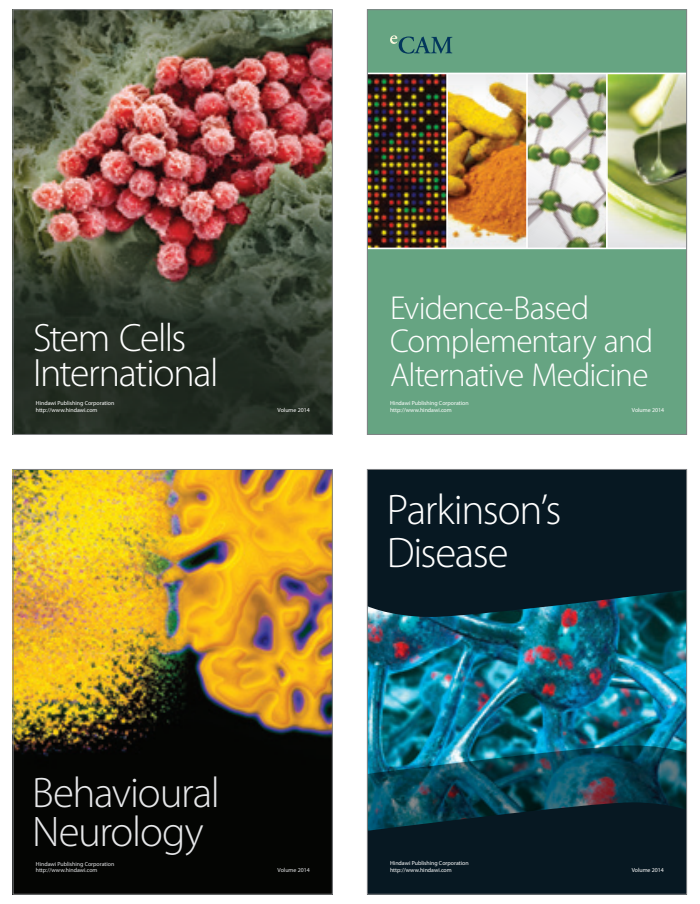
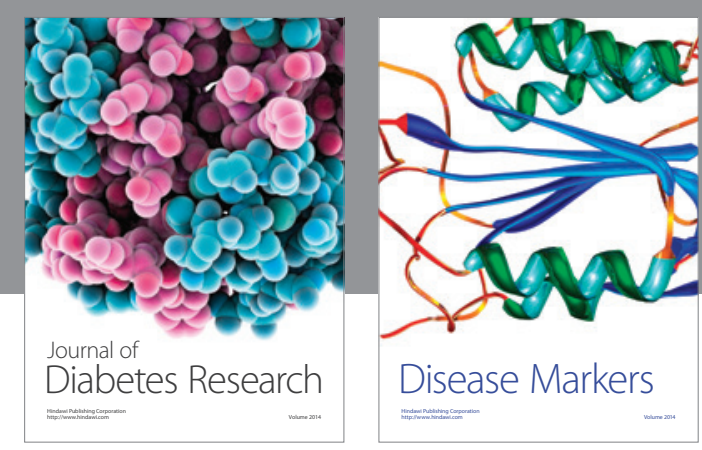

Disease Markers
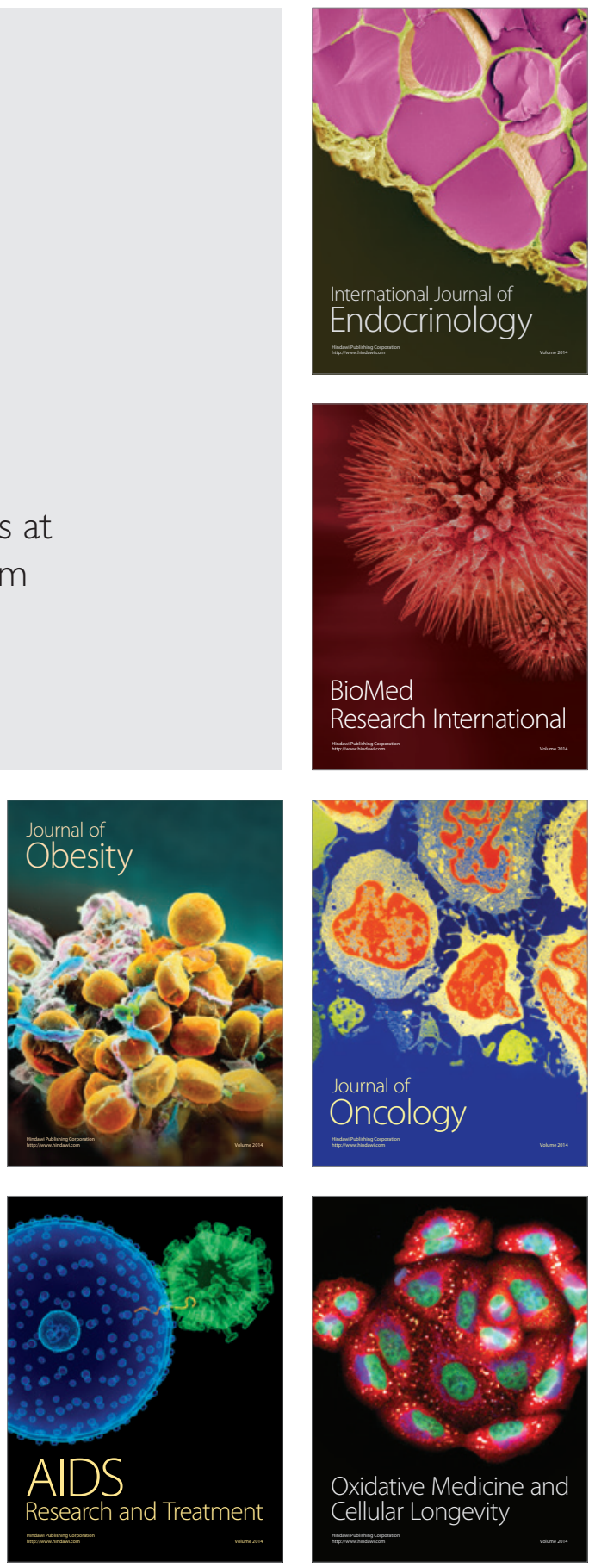